\title{
Evaluation of survival and metamorphosis of larvae of Caligus rogercresseyi (Boxshall and Bravo, 2000) (Crustacea, Copepoda) in Chile, depending on temperature, salinity and oxygen
}

\author{
A. Mardones ${ }^{a, b *}$, V. Gajardo ${ }^{a}$, M. I. Pizarro ${ }^{a}$, A. Augsburger, , R. Vega ${ }^{a, b}$, F. Encina ${ }^{d, e}$, \\ C. Pichara a and P. De los Ríos Escalanted,e
}

\begin{abstract}
aDepartamento de Ciencias Agropecuarias y Acuícolas, Facultad de Recursos Naturales, Universidad Católica de Temuco, Casilla 15-D, Temuco, Chile.

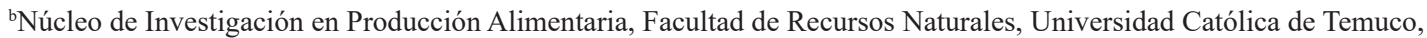
Temuco, Chile.

'Universidad Santo Tomás, Sede Puerto Montt, Chile.

dDepartamento de Ciencias Biológicas y Químicas, Facultad de Recursos Naturales, Universidad Católica de Temuco, Casilla 15-D, Temuco, Chile.

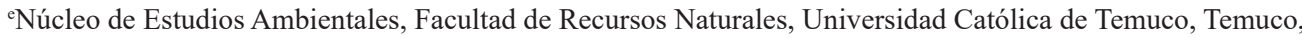
Casilla 15-D, Temuco, Chile.

*e-mail: mardolaz@uct.cl
\end{abstract}

Received: December 7, 2016 - Accepted: September 21, 2017 - Distributed: May 31, 2019

(With 6 figures)

\begin{abstract}
The present study assessed the percentage of survival and metamorphosis of larval stages of Caligus rogercresseyi (Boxshall and Bravo, 2000) nauplius I, nauplius II to and nauplius II to copepodite, conducting bioassays in triplicate with 50 larvae each, nauplius I or nauplius II, at temperature of $12{ }^{\circ} \mathrm{C}, 15^{\circ} \mathrm{C}$ and $18{ }^{\circ} \mathrm{C}$; salinity $20,23,25,2729$, 31,33 and $35 \mathrm{~g} / \mathrm{L}$ and oxygen saturation with ranges between 30-60\%, 90-100\% and $190-200 \%$. Bioassays were performed in station Quillaipe of Fundación Chile, Puerto Montt, Chile. It is concluded that the temperature is inversely proportional to the time of metamorphosis and survival of the larvae of Caligus rogercresseyi. In salinity is observed that increased this, greater is the percentage of survival and metamorphosis is faster, while the larvae do not survive less than $20 \mathrm{~g} / \mathrm{L}$. Oxygen saturation ranges indicate that the larvae do not survive at saturations between $30-60 \%$, and it had no differences between $90-100 \%$ saturation and $190-200 \%$.
\end{abstract}

Keywords: Caligus rogercresseyi, temperature, salinity, oxygen saturation.

\section{Avaliação de sobrevivência e metamorfose de larvas de Caligus rogercresseyi (Boxshall and Bravo, 2000) (Crustacea, Copepoda) no Chile, dependendo da temperatura, salinidade e oxigênio}

\begin{abstract}
Resumo
O presente estudo avaliou a percentagem de sobrevivência e metamorfose dos estádios larvais de Caligus rogercresseyi (Boxshall and Bravo, 2000) nauplio I, nauplio II ae nauplio II a copepodita, realizando bioensaios em triplicado com 50 larvas cada, nauplio I ou nauplio II, À temperatura de $12^{\circ} \mathrm{C}, 15^{\circ} \mathrm{C}$ e $18{ }^{\circ} \mathrm{C}$; Salinidade $20,23,25,2729,31,33 \mathrm{e} 35 \mathrm{~g} / \mathrm{L}$ e saturação de oxigénio com variações entre 30-60\%, 90-100\% e 190-200\%. Os bioensaios foram realizados na estação Quillaipe da Fundação Chile, Puerto Montt, Chile. Conclui - se que a temperatura é inversamente proporcional ao tempo de metamorfose e sobrevivência das larvas de Caligus rogercresseyi. Na salinidade observa-se que aumentou esta, maior é a percentagem de sobrevivência e metamorfose é mais rápida, enquanto as larvas não sobrevivem menos de $20 \mathrm{~g} / \mathrm{L}$. Os intervalos de saturação de oxigénio indicam que as larvas não sobrevivem a saturações entre 30-60\% e não têm diferenças entre $90-100 \%$ de saturação e $190-200 \%$.
\end{abstract}

Palavras-chave: Caligus rogercresseyi, temperatura, salinidade, saturação de oxigênio.

\section{Introduction}

Introduction farms, by being present in the marine environment are affected by ectoparasites on the Chilean native fauna, mainly Caligus rogercresseyi (Boxshall and
Bravo, 2000; González et al., 2016). The life cycle of the parasite consists of three planktonic states, nauplius I, nauplius II, infective copepodite, and five parasitic stages, 
chalimus I-IV or juveniles and an adult (González and Carvajal, 2003).

Infective states feed on mucus, skin and blood of its host, causing focal and hemorrhagic ulcerative skin lesions, which can be of variable severity and injury of 2 to 5 millimeters in diameter to large ulcers on the body surface, also has the potential to affect growth, fertility, and the survival of their hosts (Boxshall and Bravo 2000; González et al., 2016). In addition to being a vector of bacterial and viral diseases, such ISA, IPN, SRS (Johnson et al., 2004; Oelckers et al., 2014).

According to information provided by Technological Institute of Salmon of Chile (INTESAL), carried out between the years 2000 to 2006, in the Lakes region $\left(39-43^{\circ} \mathrm{S}\right)$, there was a decrease in the level of oxygen and an increase in mild in the salinity of the water, being these fundamental factors in the cycle of the parasite, in such a way that this situation in conjunction with other factors (wind speed, water depth, tides, circulation of water, currents, temperature and salinity patterns), productive practices and management could influence the increase of the levels of infestation by $C$. rogercressey $i$ in salmonid fish culture (Costello, 1993; Rozas \& Asencio, 2007). The aim of this work was to evaluate the effect of temperature, salinity, and oxygen saturation, on survival, and metamorphosis of larvae under controlled conditions Caligus rogercresseyi.

\section{Materials and Methods}

Adults fish individuals of Salmo salar L., were infested by $C$. rogercresseyi, female's ovigerous, which were extracted manually using fine tweezers from previously anesthetized fish with "AQUÍ-S" (proportion 1:1000, active ingredient isoeugenol $50 \%$ ). To provide an optimal environment, water filtered and sterilized sea was used by a UV intensity of $23800-25000 \mathrm{uW} / \mathrm{cm}^{2}$ with salinity of $31 \mathrm{~g} / \mathrm{L}$, ambient temperature and constant aeration.

Specimens of $C$. rogercresseyi ovigerous females, were reared in $1 \mathrm{~L}$ beakers filled with seawater $(31 \mathrm{~g} / \mathrm{L})$, each provided on average 50 larvae, the water was changed daily until 2100 larvae each bioassay to triplicate with a starting amount of 50 larvae. Every 3 hours the metamorphosis of nauplius I to nauplius II and nauplius II to copepod nauplius in all bioassays were counted until all metamorphosed or died. Counts and observations for a magnifier with $10 x$ magnification was used, the larvae were collected with a sieve of 77 microns deposited in Petri dishes with $10 \mathrm{ml}$ of water. The temperature was measured every 10 minutes using a Data - Logger, obtaining data with $\mathrm{HOBO}$ program.

Bioassay 1: Effect of temperature: three bioassays were conducted in triplicate at a constant temperature of $12^{\circ} \mathrm{C}, 15^{\circ} \mathrm{C}$ and $18{ }^{\circ} \mathrm{C}$, precipitates prepared in $90 \mathrm{ml}$ of water, with $31 \mathrm{~g} / \mathrm{L}$ salinity and aeration vessels constant. Kept in incubator refrigerator Velp model FTC 90E to maintain invariable temperature.

Bioassay 2: Effect of salinity: there were eight experiences at different salinities $(20,23,25,27,29$,
$31,33$ and $35 \mathrm{~g} / \mathrm{L}-1)$, vessels precipitated with $90 \mathrm{ml}$ of water with aeration and constant temperature $\left(15^{\circ} \mathrm{C}\right)$. The vessels were stacked in an incubator Velp model FTC $90 \mathrm{E}$, to maintain stable temperature. To obtain the expected salinity mixed freshwater with seawater or sea salt was added to obtain the desired salinity more accurately it was registered with the oxygen meter, salinity and temperature YSI model 85 - 10 FT.

Bioassay 3: Effect of oxygen saturation: to determine the effect of oxygen saturation plastic trays with $15 \mathrm{~L}$ of water is used in a $40 \mathrm{ml}$ container, with a salinity of $33 \mathrm{ppt}$. Each tray had oxygen and independent sensor diffuser to maintain saturation within the ranks of $30-60 \%, 90-100 \%$ and $190-200 \%$.

The analysis of the results included first a previous homocedasticity condition using Bartlet test, as previous condition to ANOVA, if it denotes significant differences it was applied Tukey test with a 95\% confidence level. Determining if the difference between the evaluated groups is or not significant; P values less than 0.05 indicate significant differences. The SPSS15 program was used.

\section{Results}

\subsection{Bioassay 1: effect of temperature}

Nauplius I at Nauplius II: at $18^{\circ} \mathrm{C}$ they metamorphose took 12 hours at temperatures of $12^{\circ} \mathrm{C}$ and $15^{\circ} \mathrm{C}$, it took 15 hours. Figure 1 shows that the highest percentage $12^{\circ} \mathrm{C}$ metamorphosis, with $95 \%$ survival, followed by $15{ }^{\circ} \mathrm{C}$ $(93 \%)$ and $18^{\circ} \mathrm{C}(89 \%)$, the latter having not statistically significantly different temperatures $12{ }^{\circ} \mathrm{C}$ and $15^{\circ} \mathrm{C}$ according to Table 1.

Nauplius II at Copepod: at $18^{\circ} \mathrm{C}$ showed the shortest time of metamorphosis, 36 hours, $15^{\circ} \mathrm{C}$ followed by 42 hours and finally $12{ }^{\circ} \mathrm{C}$ taking 57 hours. According to

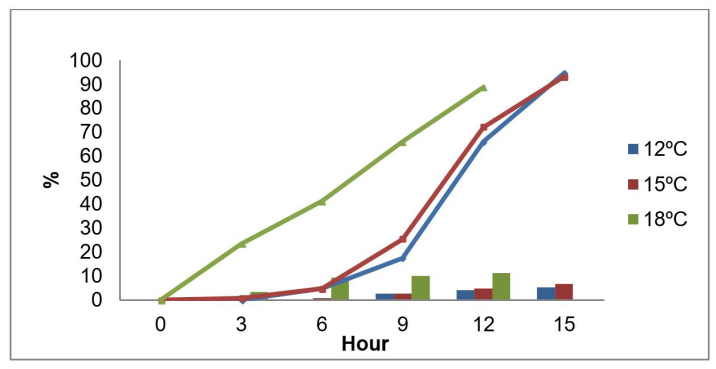

Figure 1. Metamorphosis nauplius I to nauplius II (lines) and mortality (bars) in percentage, at different temperatures.

Table 1. Statistical analysis of the survival in the metamorphosis of nauplii I, nauplii II, at different temperatures.

\begin{tabular}{ccl}
\hline Temperature $\left({ }^{\circ} \mathbf{C}\right)$ & Temperature $\left({ }^{\circ} \mathbf{C}\right)$ & \multicolumn{1}{c}{$\mathbf{P}$} \\
\hline 12 & 15 & 0.60 n.s \\
12 & 18 & $0.01^{*}$ \\
15 & 18 & $0.03^{*}$ \\
\hline
\end{tabular}

*The mean difference is significant at 0.05 . 
Figure 2 , at $12^{\circ} \mathrm{C} 91 \%$ of the nauplii II they reach their copepodite stage, showing a significant difference with $12^{\circ} \mathrm{C}$ and $18^{\circ} \mathrm{C}$, see Table 2 .

\subsection{Bioassay 2: effect of salinity}

Nauplii I to Nauplii II: metamorphosis takes 12 hours to $33 \mathrm{~g} / \mathrm{L}$ and $35 \mathrm{~g} / \mathrm{L}, 15$ hour between $20 \mathrm{~g} / \mathrm{L}, 23 \mathrm{~g} / \mathrm{L}, 27 \mathrm{~g} / \mathrm{L}$, $29 \mathrm{~g} / \mathrm{L}$ y $31 \mathrm{~g} / \mathrm{L}$ and 16 hour to $25 \mathrm{~g} / \mathrm{L}$ time being longer metamorphosis (Figure 3). Nauplii I to II, 99\% survival to $35 \mathrm{~g} / \mathrm{L}$ was obtained, showing a significant difference to $20 \mathrm{~g} / \mathrm{L}$ salinity where mortality (53\%) exceeds metamorphosis (47\%), compared to other salinities (Table 3).

Nauplius II to Copepodite: the minumum time for copepodite was 42 hours at $3 \mathrm{~g} / \mathrm{L}, 45$ hours at 20, 31 and $35 \mathrm{~g} / \mathrm{L}, 48$ hours at $29 \mathrm{~g} / \mathrm{L}, 51$ hours at 25 and $25 \mathrm{~g} / \mathrm{L}$ and it late 54 hours at $23 \mathrm{~g} / \mathrm{L}$, being it the maximum time for reach metamorphosis between salinities (Figure 4). The maximum survival was $33 \mathrm{~g} / \mathrm{L}$, with $88 \%$ and the following was $87 \%$ at $35 \mathrm{~g} / \mathrm{L}$, and the lower value was $20 \mathrm{~g} / \mathrm{L}$ with $47 \%$, existing significant differences at salinities analyzed (Table 4).

\subsection{Bioassay 3: oxygen saturation effect}

Nauplius I to Nauplius II: the metamorphosis late 12 hours at $90-100 \%$ and $190-200 \%$, whereas to $30-60 \%$ it was not evidenced metamorphosed larvae, and at 9 hours it was observed total mortality (Figure 5). The survival reaches $94 \%$ with $90-100 \%$ oxygen saturation, with $93 \%$ with $190-200 \%$, and it was obtained significant differences between $30-60 \%$ (Table 5) due that in this value was observed $100 \%$ mortality.

Nauplius II to Copepodite: the metamorphosis late 42 hours with $90-100 \%$ and $190-200 \%$ oxygen saturation with $30-60 \%$ survive 24 hours. The survival reached

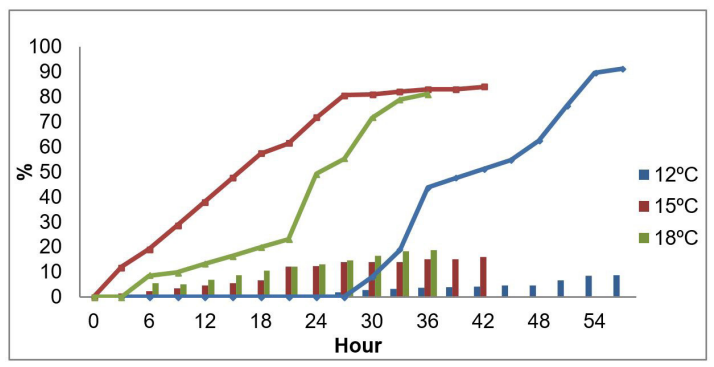

Figure 2. Metamorphosis nauplii II to copepodite (lines) and mortality (bars), as a percentage, at different temperatures.

Table 2. Statistical analysis of the survival in the metamorphosis of nauplii II to copepodite, at different temperatures.

\begin{tabular}{ccl}
\hline Temperature $\left({ }^{\circ} \mathbf{C}\right)$ & Temperature $\left({ }^{\circ} \mathbf{C}\right)$ & \multicolumn{1}{c}{$\mathbf{P}$} \\
\hline 12 & 15 & 0.07 n.s \\
12 & 18 & $0.02^{*}$ \\
15 & 18 & 0.59 n.s \\
\hline
\end{tabular}

*The mean difference is significant at 0.05 .
$87 \%$ between the range of $90-100 \%$ and $83 \%$ between $190-200 \%$ oxygen saturation, in the range between $30-60 \%$ only reached $3 \%$ survival, and this group was significant different (Figure 6, Table 6).

\section{Discussion}

The results revealed that for metamorphosis in both studied stages, and the survival is temperature dependent, and at high temperature, the metamorphosis time and survival decreased. These results agree with Tully and Whelan (1993), who mentioned that sea temperature increase is directly associated with short time parasite life cycle that in according to Bravo et al. (2009), the presence of low bodies females with low eggs chain. In according to Wootten et al. (1982), Johnson and Albright (1991), Tully and Whelan (1993), Boxaspen (1997), Wadsworth (1998), Pike and Wadsworth (1999), Bravo et al. (2013, 2014) the growth rates, eggs production, survival and recruitment are directly associated to water temperature. Also, the life cycle development was affected by salinity and oxygen saturation.

The salinity effect accelerated the parasite life cycle, at high concentration, the survival increase, at $20 \mathrm{~g} / \mathrm{L}$ the survival was low. Tucker et al. (2000) described that L. salmonis has high growth rate and recruitment at $34 \mathrm{~g} / \mathrm{L}$ in comparison to $24 \mathrm{~g} / \mathrm{L}$ salinity. The salinity does not retard the Caligus egg time production, but affect the larvae survival in analyzed studies, in according to Gonzalez and Carvajal (2003), salinities lower than $20 \mathrm{~g} / \mathrm{L}$ does
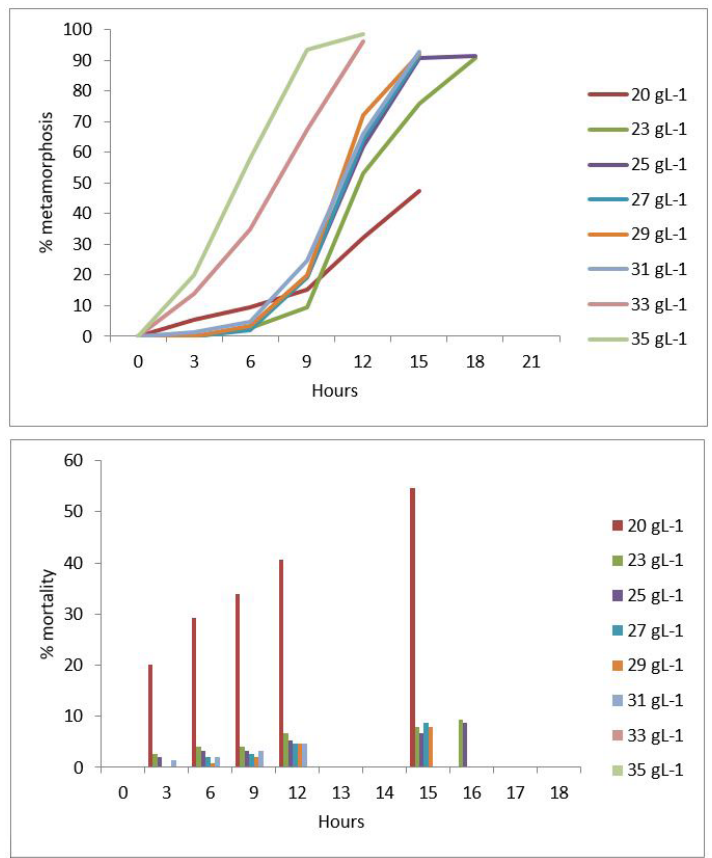

Figure 3. Metamorphosis nauplii I to nauplii II (lines) and mortality (bars), as a percentage, in terms of salinity. 
Table 3. Statistical analysis of survival in the metamorphosis of nauplii I to II, at different salinities.

\begin{tabular}{cccccc}
\hline I (Salinity) $\mathbf{g} / \mathbf{L}$ & $\mathbf{J}$ (Salinity) $\mathbf{g} / \mathbf{L}$ & $\mathbf{P}$ & $\mathbf{I}$ (Salinity) $\mathbf{g} / \mathbf{L}$ & $\mathbf{J}$ (Salinity) $\mathbf{g} / \mathbf{L}$ & $\mathbf{P}$ \\
\hline 20 & 23 & $0.00^{*}$ & 25 & 27 & $1.00 \mathrm{n} . \mathrm{s}$ \\
20 & 25 & $0.00^{*}$ & 25 & 29 & $1.00 \mathrm{n} . \mathrm{s}$ \\
20 & 27 & $0.00^{*}$ & 25 & 31 & $1.00 \mathrm{n} . \mathrm{s}$ \\
20 & 29 & $0.00^{*}$ & 25 & 33 & $0.53 \mathrm{n} . \mathrm{s}$ \\
20 & 31 & $0.00^{*}$ & 25 & 35 & $0.10 \mathrm{n} . \mathrm{s}$ \\
20 & 33 & $0.00^{*}$ & 27 & 29 & $1.00 \mathrm{n} . \mathrm{s}$ \\
20 & 35 & $0.00^{*}$ & 27 & 31 & $0.99 \mathrm{n} . \mathrm{s}$ \\
23 & 25 & $1.00 \mathrm{n} . \mathrm{s}$ & 27 & 33 & $0.38 \mathrm{n} . \mathrm{s}$ \\
23 & 27 & $1.00 \mathrm{n} . \mathrm{s}$ & 27 & 35 & $0.06 \mathrm{n} . \mathrm{s}$ \\
23 & 29 & $1.00 \mathrm{n} . \mathrm{s}$ & 29 & 31 & $1.00 \mathrm{n} . \mathrm{s}$ \\
23 & 31 & $0.99 \mathrm{n} . \mathrm{s}$ & 29 & 33 & $0.67 \mathrm{n} . \mathrm{s}$ \\
23 & 33 & $0.38 \mathrm{n} . \mathrm{s}$ & 29 & 35 & $0.16 \mathrm{n} . \mathrm{s}$ \\
& 35 & $0.06 \mathrm{n} . \mathrm{s}$ & 31 & 33 & $0.85 \mathrm{n} . \mathrm{s}$ \\
& & & 31 & 35 & $0.25 \mathrm{n} . \mathrm{s}$ \\
\hline
\end{tabular}

*The mean difference is significant at 0.05 .

Table 4. Statistical analysis of survival in the metamorphosis of nauplii II to copepodite, in terms of salinity.

\begin{tabular}{cccccc}
\hline I (Salinity) $\mathbf{g} / \mathbf{L}$ & $\mathbf{J}$ (Salinity) $\mathbf{g} / \mathbf{L}$ & $\mathbf{P}$ & $\mathbf{I}$ (Salinity) $\mathbf{g} / \mathbf{L}$ & $\mathbf{J}$ (Salinity) $\mathbf{g} / \mathbf{L}$ & $\mathbf{P}$ \\
\hline 20 & 23 & $0.00^{*}$ & 25 & 27 & $1.00 \mathrm{n} . \mathrm{s}$ \\
20 & 25 & $0.00^{*}$ & 25 & 29 & $1.00 \mathrm{n} . \mathrm{s}$ \\
20 & 27 & $0.00^{*}$ & 25 & 31 & $1.00 \mathrm{n} . \mathrm{s}$ \\
20 & 29 & $0.00^{*}$ & 25 & 33 & $0.94 \mathrm{n} . \mathrm{s}$ \\
20 & 31 & $0.00^{*}$ & 25 & 35 & $0.99 \mathrm{n} . \mathrm{s}$ \\
20 & 33 & $0.00^{*}$ & 27 & 29 & $1.00 \mathrm{n} . \mathrm{s}$ \\
20 & 35 & $0.00^{*}$ & 27 & 31 & $1.00 \mathrm{n} . \mathrm{s}$ \\
23 & 25 & $0.94 \mathrm{n} . \mathrm{s}$ & 27 & 33 & $0.97 \mathrm{n} . \mathrm{s}$ \\
23 & 27 & $0.89 \mathrm{n} . \mathrm{s}$ & 27 & 35 & $0.99 \mathrm{n} . \mathrm{s}$ \\
23 & 29 & $0.83 \mathrm{n} . \mathrm{s}$ & 29 & 31 & $1.00 \mathrm{n} . \mathrm{s}$ \\
23 & 31 & $0.68 \mathrm{n} . \mathrm{s}$ & 29 & 33 & $0.99 \mathrm{n} . \mathrm{s}$ \\
23 & 33 & $0.35 \mathrm{n} . \mathrm{s}$ & 29 & 35 & $1.00 \mathrm{n} . \mathrm{s}$ \\
& 35 & $0.51 \mathrm{n} . \mathrm{s}$ & 31 & 33 & $1.00 \mathrm{n} . \mathrm{s}$ \\
\end{tabular}

*The mean difference is significant at 0.05 .

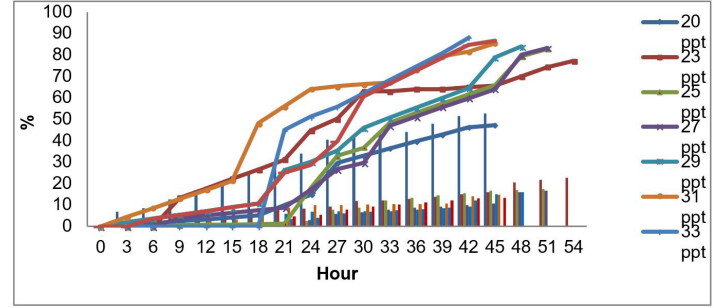

Figure 4. Metamorphosis nauplii II to copepodite (lines) and mortality (bars), as a percentage, different salinities.

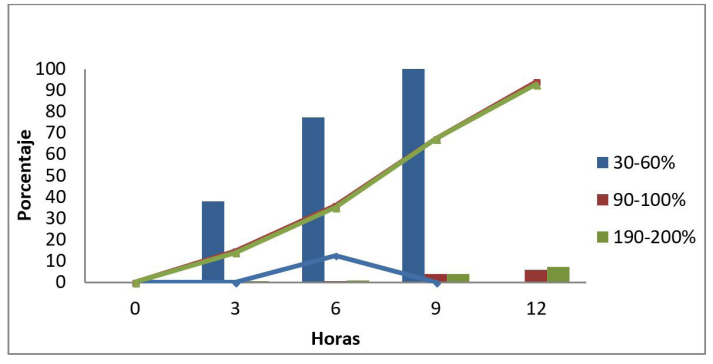

Figure 5. Metamorphosis nauplii I to nauplii II (lines) and mortality (bars), as a percentage, different percentages of oxygen saturation. 
Table 5. Statistical analysis of survival in the metamorphosis of nauplii I to nauplii II, at different oxygen saturations.

\begin{tabular}{ccc}
\hline (I) Oxygen \% & (J) Oxygen \% & Sig. \\
\hline $30-60$ & $90-100$ & 0.00 \\
$30-60$ & $190-200$ & 0.00 \\
$90-100$ & $190-200$ & 0.73 \\
\hline
\end{tabular}

The mean difference is significant at 0.05 .

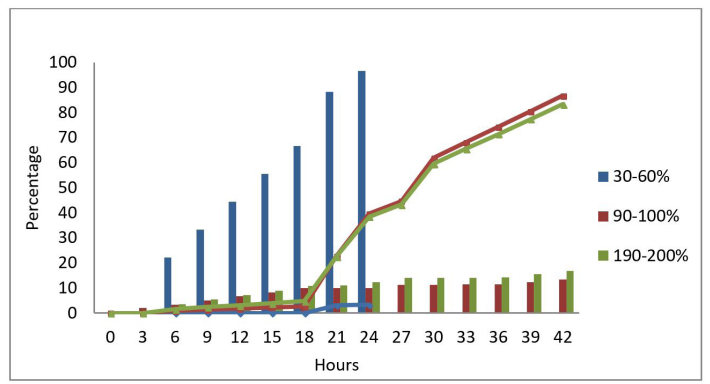

Figure 6. Metamorphosis nauplii II to copepodite (lines) and mortality (bars), as a percentage, different percentages of oxygen saturation.

Table 6. Statistical analysis of survival in the metamorphosis of nauplii II to copepodite, at different levels of oxygen saturation.

\begin{tabular}{ccc}
\hline (I) Oxygen \% & (J) Oxygen \% & Sig. \\
\hline $30-60$ & $90-100$ & 0.00 \\
$30-60$ & $190-200$ & 0.00 \\
$90-100$ & $190-200$ & 0.54 \\
\hline
\end{tabular}

The mean difference is significant at 0.05 .

not allow the survival of Nauplius and copepodite stages. It was showed that $C$. rogercresseyi does not survive at low oxygen concentration, and it reach $100 \%$ mortality between $30-60 \%$ in Nauplius II, and $97 \%$ in copepodite stages. At oxygen saturation upper than $90 \%$ it was not differences in time and survival. In according to the data base of Phytoplankton Monitooring Program of INTESAL done between 2000 to 2006, in Lakes region it was observed an oxygen decrease and a weak salinity increase, that are main factors in parasite life cycle, and in this scenario, these factors would affect the infestation rate by $C$. rogercresseyi (Rozas and Asencio, 2007; Bravo et al., 2014).

\section{Acknowledgements}

The present study was funded by Fundación Chile the area Recursos Marinos, Aquadvise and project MECESUP UCT 0804, and the authors express their gratitude to M.I for her valuable comments for improve the manuscript.

\section{References}

BOXASPEN, K., 1997. Geographical and temporal variation in abundance of salmon lice (Lepeophtheirus salmonis) on salmon (Salmo salar L.). ICES Journal of Marine Science, vol. 54, no. 6, pp. 1144-1147. http://dx.doi.org/10.1016/S1054-3139(97)80020-3.
BOXSHALL, G.A. and BRAVO, S., 2000. On the identity of the common Caligus (Copepoda: Siphonostomatoida: Caligidae) from salmonid net pen systems in southern Chile. Contributions to Zoology (Amsterdam, Netherlands), vol. 69, pp. 137-146.

BRAVO, S., ERRANZ, F. and LAGOS, C., 2009. A comparison of sea lice, Caligus rogercresseyi, fecundity in four areas in southern Chile. Journal of Fish Diseases, vol. 32, no. 1, pp. 107-113. http:// dx.doi.org/10.1111/j.1365-2761.2008.01012.x. PMid:19245635.

BRAVO, S., POZO, V., SILVA, M.T. and ABARCA, D., 2013. Comparison of the fecundity rate of Caligus rogercresseyi infesting Atlantic salmon (Salmo salar L.) on farms in two regions of Chile. Aquaculture (Amsterdam, Netherlands), vol. 404/405, pp. 55-58. http://dx.doi.org/10.1016/j.aquaculture.2013.04.002.

BRAVO, S., SILVA, M.T. and TREASURER, J., 2014. Factors affecting the abundance of Caligus rogercresseyi (Boxshall and Bravo) on farmed salmonids in Chile in the period 2006-2007. Aquaculture (Amsterdam, Netherlands), vol. 434, pp. 456-461. http://dx.doi.org/10.1016/j.aquaculture.2014.09.009.

COSTELLO, M.J. 1993. Review of methods to control sea lice (Caligidae Crustacea) infestations on salmon (Salmo salar) farms. In: G.A. Boxshall and D. Defaye. Pathogens of wild and farmed fish: sea lice. Chichester: Ellis Horwood, pp. 219-252.

GONZÁLEZ, L. and CARVAJAL, J., 2003. Life cycle of Caligus rogercresseyi, (Copepoda:Caligidae) parasite of Chilean reared salmonids. Aquaculture (Amsterdam, Netherlands), vol. 220, no. 1-4, pp. 101-117. http://dx.doi.org/10.1016/S0044-8486(02)00512-4.

GONZALEZ, M.P., MUÑOZ, J.L.P., VALERIO, V. and VARGAS-CHACOFF, L., 2016. Effects of the ectoparasite Caligus rogercresseyi on Salmo salar blood parameters under farm conditions. Aquaculture (Amsterdam, Netherlands), vol. 457, pp. 29-34. http://dx.doi.org/10.1016/j.aquaculture.2016.01.027.

JOHNSON, S.C. and ALBRIGHT, L.J., 1991. Development, growth, and survival of Lepeophtheirus salmonis (Copepoda: Caligidae) under laboratory conditions. Journal of the Marine Biological Association of the United Kingdom, vol. 71, no. 02, pp. 425-436. http://dx.doi.org/10.1017/S0025315400051687.

JOHNSON, S.C., TREASURER, J.W., BRAVO, S., NAGASAWA, K. and KABATA, Z., 2004. A review of the impacts of parasitic copepods on marine aquaculture. Zoological Studies (Taipei, Taiwan), vol. 43, pp. 229-243.

OELCKERS, K., VIKE, S., DUESUND, H., GONZALEZ, J., WADSWORTH, S. and NYLUND, A., 2014. Caligus rogercresseyi as a potential vector for transmission of infectious salmon anemia (ISA) virus in Chile. Aquaculture (Amsterdam, Netherlands), vol. 420/421, pp. 126-132. http://dx.doi.org/10.1016/j. aquaculture.2013.10.016.

PIKE, A.W. and WADSWORTH, S.L., 1999. Sealice on salmonids: their biology and control. Advances in Parasitology, vol. 44, pp. 233-337. http://dx.doi.org/10.1016/S0065-308X(08)60233-X. PMid:10563397.

ROZAS, M. and ASENCIO, G., 2007. Assessment of epidemiologic situation of caligiasis in Chile: toward to effective control strategy. Salmo ciencia. Instituto Tecnológico del Salmón, vol. 2, pp. 43-59.

TUCKER, C.S., SOMMERVILLE, C. and WOOTTEN, R., 2000. The effect of temperature and salinity on the settlement and survival of copepodids of Lepeophtheirus salmonis (Krøyer, 1837) on Atlantic salmon, Salmo salar L. Journal of Fish Diseases, 
vol. 23, no. 5, pp. 309-320. http://dx.doi.org/10.1046/j.13652761.2000.00219.x.

TULLY, O. and WHELAN, K.F., 1993. Production of nauplii of Lepeophtheirus salmonis (Krøyer) (Copepoda: Caligidae) from farmed and wild salmon and its relation to the infestation of wild sea trout (Salmo trutta L.) off the west coast of Ireland in 1991. Fisheries Research, vol. 17, no. 1-2, pp. 187-200. http://dx.doi. org/10.1016/0165-7836(93)90018-3.
WADSWORTH, S. 1998. Studies on the biology and control of sea lice Lepeophtheirus salmonis. Aberdeen, Scotland United Kingdom: University of Aberdeen. PhD Thesis.

WOOTTEN, R., SMITH, J.W. and NEEDHAM, E.A. 1982. Aspects of the biology of the parasitic copepods Lepeophtheirus salmonis and Caligus elongatus on farmed salmonids, and their treatment. Proceedings of the Royal Society of Edinburgh, Section B: Biological Sciences, vol. 81, pp. 185-197. https:// doi.org/10.1017/S0269727000003389. 